\title{
Pyrrhotite and associated sulphides and their relationship to acid rock drainage in the Halifax Formation, Meguma Group, Nova Scotia
}

\author{
Don Fox, Clare Robinson and Marcos Zentilli \\ Department of Earth Sciences, Dalhousie University, Halifax, Nova Scotia B3H 3J5, Canada
}

\author{
Date Received April 17, 1997 \\ Date Accepted July 4, 1997
}

\begin{abstract}
The physical disruption of sulphide-bearing metasedimentary rocks of the Halifax Formation leads to oxidation of iron-sulphide minerals and the generation of acid rock drainage (ARD). Although pyrrhotite occurs in many places throughout the Halifax Formation, previous ARD studies have not considered in detail the mineral chemistry, texture, and distribution of this mineral nor how these factors may potentially influence the development of ARD. For this study, pyrrhotite-bearing samples of the Halifax Formation were collected in the field and from drill core at four locations in southwestern Nova Scotia. Samples were taken from different geological settings, such as proximal and distal to granitic intrusions and from different stratigraphic positions, to obtain a variety of mineral assemblages. Petrographic, microprobe and $\mathrm{X}$-ray diffraction work indicate that the pyrrhotite in all samples is mainly monoclinic $\mathrm{Fe}_{7} \mathrm{~S}_{8}$, and its composition is relatively homogeneous regardless of geological environment. Inclusions of chalcopyrite and detectable quantities of $\mathrm{As}$, $\mathrm{Co}$ and $\mathrm{Ni}$ are common. In regionally metamorphosed, greenschist-facies areas, pyrrhotite is preferentially aligned along cleavage planes and thus is easily accessible to oxidizing air and fluids. Because pyrrhotite is regionally developed, contains potentially toxic trace elements, and occurs along cleavage planes, it is considered to play a significant role in ARD development in the Halifax Formation. Also, pyrrhotite oxidizes substantially faster than many other sulphide minerals and may be especially significant in the early stages of ARD.
\end{abstract}

La dislocation physique des roches métasédimentaires sulfurifères de la Formation d'Halifax mène à une oxydation des minéraux renfermant du sulfure de fer ainsi qu'à la production d'exhaures de roches acide (ERA). Même si on relève la présence de pyrrhotine en de nombreux endroits partout à l'intérieur de la Formation d'Halifax, les études antérieures des ERA ne se sont pas attardées de façon approfondie sur la nature chimique minérale, la texture et la répartition de ce minéral ni sur la manière dont ces facteurs peuvent éventuellement influer sur l'apparition des ERA. Les chercheurs ont, aux fins de cette étude, prélevé sur le terrain ainsi que sur des carottes de sondage à quatre emplacements dans le sud-ouest de la Nouvelle-Écosse, des échantillons de la Formation d'Halifax renfermant de la pyrrhotine. On a prélevé les échantillons de différents cadres géologiques stratigraphiques, comme des intrusions proximales et distales à granitiques et différentes positions stratigraphiques, afin d'obtenir toute une variété d'associations minéralogiques. Des travaux à la microsonde, de diffraction aux rayons $\mathrm{X}$ et pétrographiques révèlent que la pyrrhotine de tous les échantillons est essentiellement du $\mathrm{F}_{7} \mathrm{~S}_{8}$ monoclinique et qu'elle est d'une composition relativement homogène, peu importe l'environnement géologique. Les inclusions de chalcopyrite et de quantités détectables d'As, de Co et de Ni sont courantes. Dans les secteurs des faciès des schistes verts régionalement métamorphisés, la pyrrhotine est principalement alignée le long de plans de clivage et elle est ainsi facilement accessible aux fluides et à l'air oxydants. Vu la présence régionale de la pyrrhotine, vu qu'elle renferme des éléments traces pouvant être toxiques et vu qu'elle se trouve le long de plans de clivage, on considère qu'elle joue un rôle prépondérant dans la production des ERA à l'intérieur de la Formation d'Halifax. La pyrrhotine s'oxyde par ailleurs beaucoup plus rapidement que de nombreux autres minéraux sulfurés et ce facteur peut être particulièrement déterminant dans les premiers stades de la production des ERA.

[Traduit par la rédaction]

\section{INTRODUCTION}

Acid rock drainage (ARD) results mainly from the oxidation of iron-sulphide minerals. Pyrite $\left(\mathrm{FeS}_{2}\right)$ and pyrrhotite $\left(\mathrm{Fe}_{1-\mathrm{x}} \mathrm{S}\right)$ are two of the most common iron-sulphide minerals in areas where ARD is prevalent. However, other sulphide minerals such as sphalerite $(\mathrm{Zn}(\mathrm{Fe}) \mathrm{S})$, galena $(\mathrm{PbS})$, arsenopyrite (FeAsS) and chalcopyrite $\left(\mathrm{CuFeS}_{2}\right)$ are also important, especially for the possible release of trace elements into the environment. It is now well established that different sulphide minerals have different relative rates of reac- tivity and it is widely accepted that pyrrhotite oxidizes substantially faster than pyrite, under both chemically and biologically controlled oxidizing conditions (e.g., Bhatti et al., 1993; Jambor, 1994; Nicholson, 1994; Nicholson and Scharer, 1994). For example, under controlled laboratory conditions $\left(22^{\circ} \mathrm{C}\right.$ and atmospheric concentrations of $\left.\mathrm{O}_{2}\right)$, the abiotic oxidation rate of pyrrhotite was found to be on the order of 100 times faster than the oxidation rate of pyrite (Nicholson and Scharer, 1994). Therefore, an abundance of pyrrhotite has the potential to oxidize and create ARD in the surrounding environment at much faster rates than pyrite. This situation 
could have a detrimental affect on the surrounding ecosystem by creating toxic pulses of metal-rich ARD in shorter time periods compared to pyrite.

According to Nicholson and Scharer (1994), the oxidation of pyrrhotite is not a very well understood process compared to that of pyrite, and the rate controls on the reactions and the oxidation products are poorly known. Recently, however, pyrrhotite has become the focus of much research (e.g., Jones et al., 1992; Bhatti et al., 1993; Nicholson, 1994; Mycroft et al., 1995; Pratt et al., 1996). In its simplest form, the overall oxidation of pyrrhotite by oxygen is illustrated by the general equation (Nicholson, 1994):

$F e_{(1-x)} \mathrm{S}+\left(2-\frac{\mathrm{x}}{2}\right) \mathrm{O}_{2}+(x) \mathrm{H}_{2} \mathrm{O} \Leftrightarrow(1-x) \mathrm{Fe}^{2+}+\mathrm{SO}_{4}^{2-}+(2 x) \mathrm{H}^{+}$

In this equation, $x$ represents the iron-deficiency in pyrrhotite and can vary from 0.0 to 0.125 . At the end member where $x=0$ (troilite - FeS) no $\mathrm{H}^{+}$ions are produced. However, the end-member where $x=0.125$ (monoclinic pyrrhotite $-\mathrm{Fe}_{7} \mathrm{~S}_{8}$ ) leads to the maximum amount of $\mathrm{H}^{+}$ions produced. In this case, one mole of $\mathrm{Fe}_{7} \mathrm{~S}_{8}$ leads to $1 / 4$ mole of $\mathrm{H}^{+}$ions being produced. Therefore, for pyrrhotite, the amount of $\mathrm{H}^{+}$ions released into solution depends on its composition (and therefore structural type). In theoretical terms based on simple balanced chemical reactions, of all the possible types of pyrrhotite minerals, monoclinic pyrrhotite $\left(\mathrm{Fe}_{7} \mathrm{~S}_{8}\right)$ will result in the highest amount of acidity released into the surrounding environment. However, it should be noted that with a typical value of $x=0.1$ in pyrrhotite, oxidation still only produces about one-tenth as much acid as pyrite (Nicholson, 1994). Pyrrhotite oxidation may be especially important in the early stages of ARD development.

It has been speculated that the iron-deficiency in the pyrrhotite crystal structure may have an affect on pyrrhotite oxidation kinetics and that monoclinic pyrrhotite oxidizes faster than hexagonal pyrrhotite, although no estimation of the actual rates was given (Nicholson, 1994). More recently, it has been shown that specific surface area of pyrrhotite crystals appears to be a dominant control on reaction kinetics under conditions of oxidation by ferric iron, oxidation by dissolved oxygen and non-oxidative dissolution (Janzen et al., 1997). The rate of pyrrhotite oxidation, and perhaps more importantly the oxidation of sulphide minerals in association with pyrrhotite, may also be affected through galvanic processes (Natarajan, 1990; Kwong and Lawrence, 1994). Under galvanic conditions, the rate of oxidation may depend on such factors as the type and size of sulphide minerals in contact with pyrrhotite, as well as the nature and duration of the contact (Natarajan, 1990). It has also been suggested that trace metal content in sulphide minerals can affect oxidation rates (Kwong and Lawrence, 1994). Regardless, an understanding of the trace metal content is also important due to their possible release into the surrounding environment.

These factors that may affect pyrrhotite oxidation and ARD development are further complicated by the fact that, in nature, pure pyrrhotite phases are relatively uncommon and most crystals consist of intergrowths of monoclinic and hexagonal phases (e.g., Arnold, 1967). The type and abundance of intergrowths depend on many factors but prevailing thermal conditions, availability of hydrothermal solutions and degree of anisotropic stress (i.e., metamorphic and structural history) are important (Lianxing and Vokes, 1996).

Pyrrhotite is known to be regionally distributed throughout much of the Halifax Formation in Nova Scotia. Although a quantitative estimate of pyrrhotite abundance for the entire Halifax Formation is impossible, mainly because of lack of detailed mapping and attention to sulphide minerals in general, previous workers have generally estimated $10 \mathrm{wt} . \%$ or less in specific areas (e.g., Schwarz and McGrath, 1974; Binney et al., 1986; Haysom et al., 1997). The purpose of this paper is to present the results of a study of the pyrrhotite mineralogy in a suite of samples selected from a diverse range of geologic environments within the Halifax Formation. The focus is on the determination of texture, structural type, and major and trace element content of pyrrhotite and other sulphide minerals associated with pyrrhotite. The actual development of ARD under natural conditions depends on a number of factors including prevailing environmental conditions (e.g., temperature, amount of rainfall), availability of oxidants such as $\mathrm{O}_{2}$ and $\mathrm{Fe}^{3+}$, and the presence or absence of bacteria. Therefore we view this study as a first step that will lead to a better understanding of the acid generating process in the Halifax Formation, and may also aid in the prediction, prevention and eventual remediation of $A R D$ sites.

\section{Regional GeOLOGY}

The Cambro-Ordovician Meguma Group crops out throughout much of southern Nova Scotia (Fig. 1) and consists of an interstratified assemblage of clastic metasedimentary rocks approximately 12 to $14 \mathrm{~km}$ thick (Schenk, 1970). The Meguma Group consists of a lower unit of thickly bedded metasandstone with thin slate interbeds (Goldenville Formation) and an upper unit of slate with thin metasiltstone interbeds (Halifax Formation). The transition between the two formations is informally referred to as the Goldenville-Halifax Transition zone (GHT) (Zentilli et al., 1986). The GHT contains a distinctive marker unit consisting of finely laminated, manganiferous argillite that contains calcareous or calc-silicate nodules and spessartine coticules (Graves and Zentilli, 1988). Thickness of the GHT varies from less than $50 \mathrm{~m}$ at Eastville (Binney et al., 1986) to $2 \mathrm{~km}$ in the Mahone Bay area (O'Brien, 1986).

During the Devonian Acadian Orogeny, the Meguma Group was intruded by granitoid rocks, the largest body of which is the South Mountain Batholith (e.g., Fairbairn et al., 1960). Regional metamorphism from greenschist to amphibolite facies, as well as contact metamorphism related to the granitoid intrusions, has affected the Meguma Group (Taylor and Schiller, 1966). Major, kilometer-scale, upright folds trending east-west are developed throughout the Meguma Group, with axial traces approximately parallel to the coastline of southwestern Nova Scotia (Keppie, 1979b). Spaced cleavage 


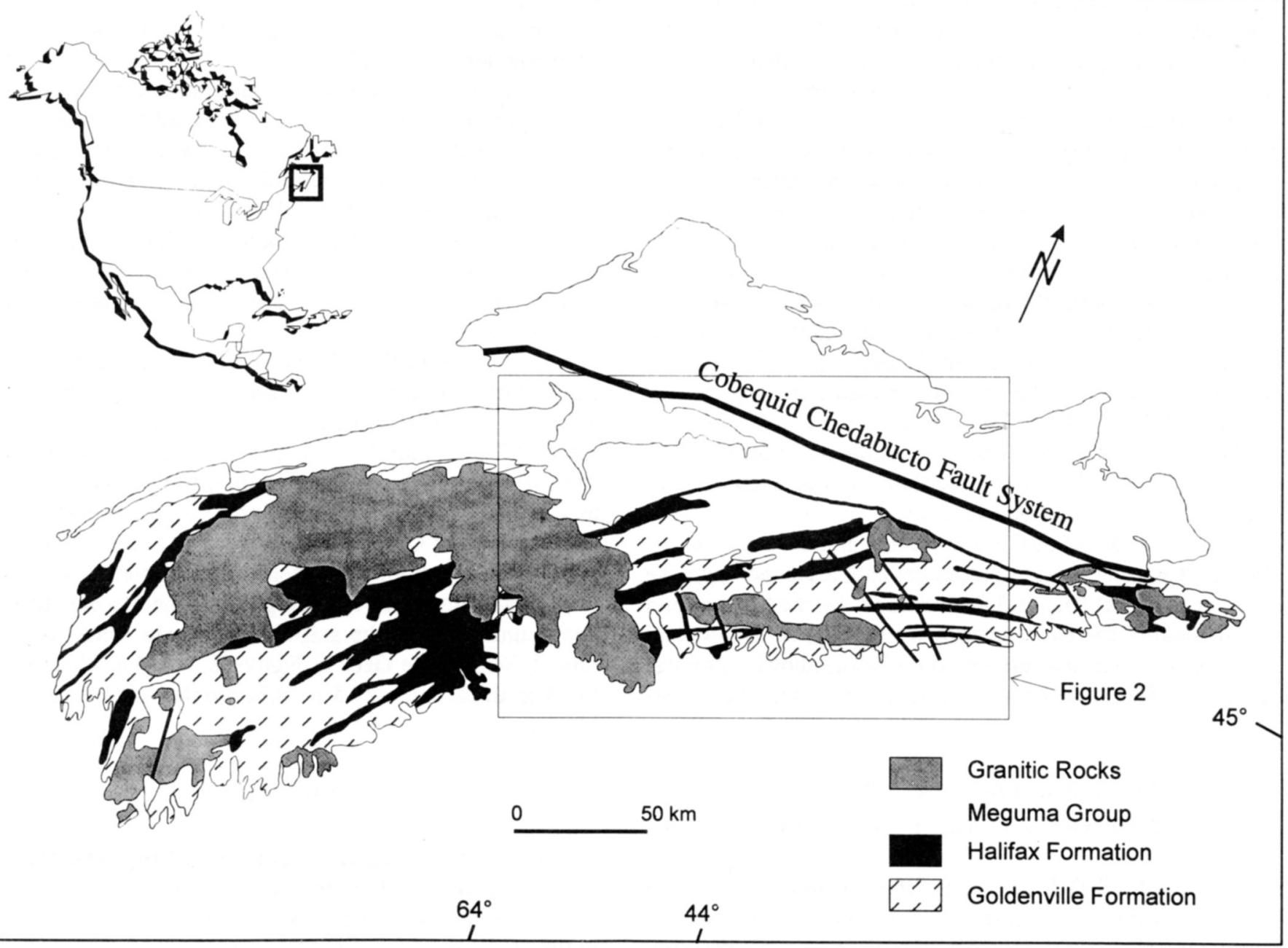

Fig. 1. Simplified geological map of Nova Scotia showing distribution of the Meguma Group and granitic rocks (modified from Keppie, 1979a).

is well developed in metasandstone of the Goldenville Formation and slaty cleavage is well developed throughout the Halifax Formation (Henderson et al., 1986).

\section{ACID ROCK DRainage from the Halifax Formation}

Disruption of the sulphide-bearing metasedimentary rocks of the Halifax Formation results in the development of ARD that has caused serious and costly environmental problems in Nova Scotia (e.g., King, 1985; Manchester, 1986; Hennigar and Gibb, 1987; Worgan, 1987). For example, ARD resulting from construction activities is a serious problem at the Halifax International Airport (HIA). Acidic drainage at the airport site has probably occurred since construction began in the mid 1950s although the first recorded fish kill in the Shubenacadie River, approximately $6 \mathrm{~km}$ north of the HIA, occurred late in the summer of 1960 (Worgan, 1987). Eight fish kills correlating to construction activity at the HIA were recorded in the Shubenacadie River between 1960 and 1976 (Worgan, 1987). It has also been demonstrated that ARD from the HIA has resulted in severely degraded water qual- ity and aquatic habitat in receiving streams in the headwater region of the $50 \mathrm{~km}^{2}$ Salmon River watershed to the south (Porter Dillon Limited, 1985). In this area, ARD is treated through a lime treatment facility before discharging into McDowell Brook; however, only about 50\% of ARD actually gets treated (Lund et al., 1987). Untreated ARD bypasses the treatment facility through a stormwater interceptor drain and through groundwater leakage. Lund et al. (1987) estimated approximately $16,000 \mathrm{~kg} /$ year Al and $250,000 \mathrm{~kg} /$ year acidity by-pass the treatment facility and discharge directly into McDowell Brook. Total expenditures for remediation efforts at the HIA are unknown but millions of dollars have been spent. Examples include the capping of a waste rock pile at a cost of $\$ 800,000$, construction of a treatment facility $(\$ 500,000)$, and operation and maintenance of the treatment facility that has cost $\$ 240,000$ annually since 1982 (Worgan, 1987).

Additional problem areas in Nova Scotia relating to ARD from the Halifax Formation have also been documented. ARD has resulted from construction of Highway 107 near Petpeswick Lake (approximately $20 \mathrm{~km}$ east of the city of Halifax), where a trench approximately $0.5 \mathrm{~km}$ in length exposed continu- 
ous outcrops of the Halifax Formation up to $5 \mathrm{~m}$ high (Jacques, Whitford and Associates Limited, 1990). Remedial efforts included capping of the exposed slate with shotcrete and the construction and operation of a small treatment facility. In 1977, fish kills in the Mahone Bay area of southwestern Nova Scotia resulted when crushed slate was used to resurface a secondary road (Thompson, 1978; Pettipas, 1979). Manchester (1986) found an average $\mathrm{pH}$ of 3.78 in standing water bodies in 50 slate quarries in the Mahone Bay area. Kerekes et al. (1984) documented the acidification (mean $\mathrm{pH}$ 's of 3.6 and 4.0) of two lakes located approximately 15 km north of the city of Halifax and attributed this to sulphide oxidation from exposed slate in the drainage basin. Also, a wetland vegetated system has been installed at a quarry near the HIA (Silver, 1988). These examples of ARD areas in the Halifax Formation suggest that some ARD problem areas are still undocumented, and that the true magnitude of the problem has yet to be addressed.

The seriousness of these accidents and the high cost of abatement and ameliorative procedures have led to the "Sulphide Bearing Material Disposal Regulations" by the Nova Scotia Department of the Environment which require lithological sampling and predictive test procedures before allowing physical disruption of sulphide-bearing rocks (Environment Act, 199495, c.1, s.1).

\section{AbUndance and Regional distribution of sulphide minerals in the Halifax Formation}

Although ARD from the Halifax Formation has been well known for many years, there is a lack of information concerning the detailed mineralogical aspects of this problem. In particular, the abundance, type, texture, size, trace element content and regional distribution of sulphide minerals, as well as their relationship to carbonate and silicate minerals has not been well documented. For example, it is only recently that the mineralogy of drill core samples from the HIA have been studied in detail (Knee, 1995; Pasava et al., 1995). Both studies have concluded that monoclinic pyrrhotite is the predominant sulphide mineral but pyrite, marcasite, arsenopyrite and chalcopyrite are also present.

Regional-scale magnetic anomalies over the Halifax Formation in Nova Scotia are caused by the presence of pyrrhotite (McGrath, 1970; Schwarz and Broome, 1994; King, 1997). Average concentrations of 6 to $12 \mathrm{wt}$ \% (determined by geophysical modelling techniques) and 2 wt.\% (determined in a small number of surface samples) have been suggested (Schwarz and Broome, 1994). The discrepancy in estimated pyrrhotite concentrations is discussed in detail by Schwarz and Broome (1994) and may be due to weathering of surface samples or by limitations of the geophysical modelling technique used.

Schwarz and Broome (1994) citing P. McGrath (personal communication) considered that magnetic anomalies in the Halifax Formation near granitic intrusions likely result from local concentrations of magnetite but no mention was made of the occurrence of sulphide minerals in such areas. However, O'Brien (1986) reported that pyrite and pyrrhotite are the common sulphide minerals in contact metamorphic aureoles, although the relative abundance of each was not estimated. Samostie (1994) reported that pyrite is virtually absent from the Halifax Formation within 2 $\mathbf{k m}$ of granitic intrusions, and concluded that risk of ARD in these areas is greatly reduced. However, no mention of pyrrhotite or other sulphide minerals was given, although an adequate assessment of ARD risk can only be done after all mineralogical details are known. Hence, the need for more mineralogical observations in contact metamorphosed rocks of the Halifax Formation is vital for the assessment of $A R D$ in such areas.

Lithologies within the GHT also have the potential to cause ARD problems. Based on a regional sampling program, the GHT was found to be a significant control for metals (Graves and Zentilli, 1988). Some calcareous argillite and black slate units are preferentially enriched in $\mathbf{M n}$, total $\mathrm{C}, \mathrm{Ba}, \mathrm{Pb}, \mathrm{Zn}, \mathrm{Cu}, \mathrm{Mo}, \mathrm{W}$, and $\mathrm{Au}$ over average crustal values and other GHT lithologies (Graves and Zentilli, 1988). In general, the highest concentration of metals was found to be associated with iron-sulphide minerals but the average abundances of the sulphide minerals were not determined. Within the GHT at Eastville, a bed of black slate 5 to $15 \mathrm{~m}$ thick contains 5 to $10 \%$ pyrrhotite (Binney et al., 1986).

\section{Methods}

A total of 15 rock samples from outcrops and drill core were collected from four areas of the Halifax Formation (Fig. 2). Two of the areas (Halifax and Mount Uniacke sites) are within $0.5 \mathrm{~km}$ of the South Mountain Batholith and were chosen to represent areas affected by contact metamorphism. Samples from the Beaverbank Highway site are representative of Halifax Formation rocks affected by regional greenschist facies metamorphism. Drill core from the Eastville site was sampled mainly within the GHT as interpreted by MacInnis (1986).

Samples were chosen on the basis that they contained visible sulphide mineralization and pyrrhotite was specifically targeted using a K-2 magnetic susceptibility meter. The pyrrhotite structural types of interest in this study give at least some susceptibility response because of their iron-deficiency. Polished thin sections were made from all samples and minerals were studied using petrographic and ore microscopic techniques.

A JEOL 733 electron microprobe at Dalhousie University was used to determine the composition of selected grains. The microprobe is equipped with four wavelength dispersive spectrometers and an Oxford Link eXL energy dispersive system which was used for all elements. Resolution of the energy dispersive detector was $137 \mathrm{eV}$ at $5.9 \mathrm{KeV}$. Each spectrum was acquired for $\mathbf{4 0}$ seconds with an accelerating voltage of $15 \mathrm{kV}$ and a beam current of $15 \mathrm{nA}$. Probe spot size was approximately $1 \mathrm{micron}$. The raw data was corrected using Link's ZAF matrix correction program. Instrument calibration was performed on cobalt metal. Instrument precision on cobalt metal $(n=10)$ was $\pm 0.5 \%$ at one standard 


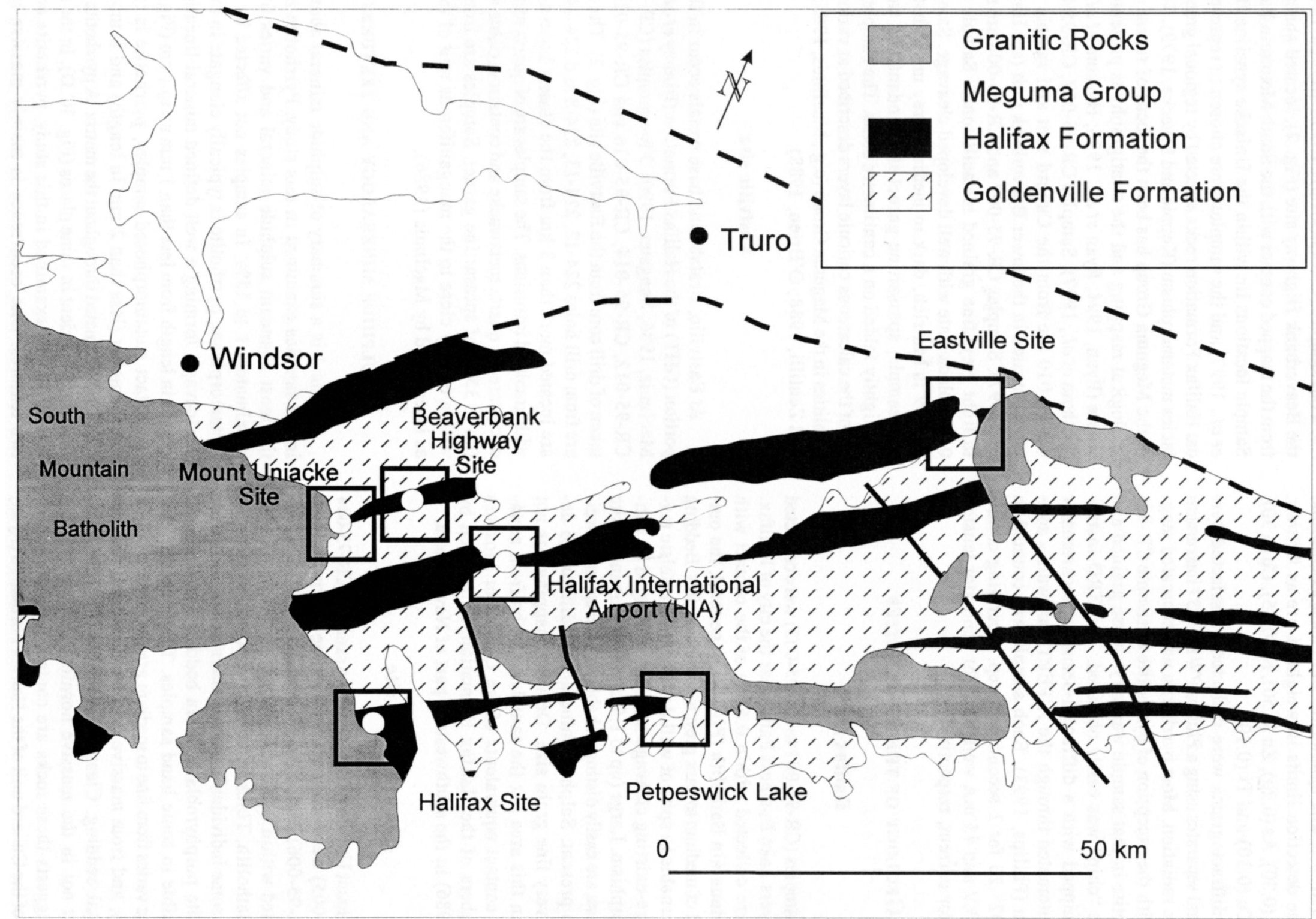

Fig. 2. Geological map showing location of sample sites. Also shown is the location of the Halifax International Airport (HIA) and Petpeswick Lake, two sites of ongoing mitigation efforts for the abatement of ARD (geology modified from Keppie, 1979a). 
deviation. Relative accuracy for major elements was \pm 1.5 to $2.0 \%$. Geological standards, including arsenopyrite, chalcopyrite, pyrrhotite, and sphalerite, were used as controls. Approximate detection limits in weight \% are as follows: $\mathrm{Fe}(0.15), \mathrm{S}(0.30), \mathrm{As}(0.20), \mathrm{Zn}(0.50), \mathrm{Ni}(0.25), \mathrm{Co}(0.30)$, $\mathrm{Cr}$ (0.15), $\mathrm{Cu}(0.30)$ and $\mathrm{Ti}(0.10)$.

$\mathrm{X}$-Ray diffractograms were collected on selected pyrrhotite mineral separates using a Philips PW1050/37 instrument with $\mathrm{Co}-\mathrm{K} \propto$ radiation. Most pyrrhotite was separated magnetically, with the exception of pyrrhotite in sample CR-95003 . Pyrrhotite in that sample was very coarse grained and a pyrrhotite "chip" was easily obtained. The XRD instrument is equipped with a diffracted-beam monochromator and fully automated through the X'PERT hardware - software system (Philips, 1993). Each sample was counted in steps of $0.02^{\circ} 2 \theta$ for 1 second per step. Operating conditions of $40 \mathrm{kV}$ and $45 \mathrm{~mA}$ were used for generator tension and generator current, respectively.

\section{Geology OF THE SAMPLE SITES}

\section{Halifax site}

Three samples (CR-95-001 to CR-95-003) were collected near the Bayers Lake Business Park, near the city of Halifax. Samples were collected within $0.5 \mathrm{~km}$ of the contact with the South Mountain Batholith (Fig. 2). In general, the outcrops consist of medium to dark grey, massive hornfels. Bedding is still discernable in spite of well developed hornfelsic texture. Any pre-existing cleavage has been destroyed by contact metamorphism. Large (up to $1.5 \mathrm{~cm}$ in length) andalusite porphyroblasts are easily distinguishable in outcrop, and cordierite is also present. Sulphide minerals are difficult to detect due to very fine grain size. Detailed mapping has not been done in this area but the samples may be from metamorphosed contact equivalents of the Cunard or Moshers Island members of the Halifax Formation, as mapped by O'Brien (1986) in the southwestern part of Nova Scotia.

\section{Mount Uniacke site}

At the Mount Uniacke site (Fig. 2), two samples (CR-95-004 and CR-95-005) were collected from a slate quarry and one sample (CR-95-006) from a road-side outcrop. All samples were collected within $0.5 \mathrm{~km}$ of the contact with the South Mountain Batholith. Thick bedding ( $1 \mathrm{~m}$ scale) is visible in outcrop and some individual beds are dominated by andalusite and cordierite porphyroblasts. Thin bedding $(\mathrm{mm}$ and $\mathrm{cm}$ scale) is visible in some hand samples. The appearance of these samples varies from fine to medium grained, from medium to dark grey, and from massive to spotted hornfels that reflects original bedding. Cleavage is present in the spotted hornfels but not in the massive hornfels. Recent detailed mapping suggests these rocks are contact metamorphosed equivalents of the Cunard unit of the Halifax Formation (Ryan, 1994; Ryan et al., 1996; Haysom et al., 1997).

\section{Beaverbank Highway site}

Four samples (CR-95-007 to CR-95-010) were taken from the Beaverbank Highway site (Fig. 2), located about $15 \mathrm{~km}$ from the mapped contact with the South Mountain Batholith. Sample locations lie within the Uniacke syncline (Haysom et al., 1997) and the samples were chosen to represent typical Halifax Formation rocks affected by regional greenschistfacies metamorphism (Keppie and Muecke, 1979). This area of the Meguma Group has been the focus of recent detailed geological mapping and the stratigraphy is presented elsewhere (Ryan, 1994; Ryan et al., 1996; Haysom et al., 1997; Feetham et al., 1997). Samples CR-95-007, CR-95-008 and CR-95-010 are from the Cunard unit and sample CR-95009 is located in the lower Beaverbank unit (see Haysom et al., 1997). Samples CR-95-007 and CR-95-008 are medium to light grey, fine grained metasiltstones. Sample CR-95010 is black slate with well developed cleavage. Sample CR95-009 is Mn-rich, dark to medium grey metasiltstone. In this sample, spessartine garnet is abundant and thin beds are tightly folded on a centimetre scale. The sample is typical of the calcareous coticule layers described at various other localities in the Meguma Group (e.g., MacInnis, 1986; Graves and Zentilli, 1988; O'Brien, 1988).

\section{Eastville site}

At Eastville, stratabound base metals occur in the basal portion (GHT) of the Halifax Formation (Binney et al., 1986; MacInnis, 1986; Sangster, 1990). Five samples (CR-95-011, CR-95-012, CR-95-014, CR-95-016 and CR-95-017) were taken of drill core from the Eastville site (Fig. 2). The samples are from drill holes 224-12, 224-13, 224-8 and 224-24, which are located more than $3 \mathrm{~km}$ from the closest known contact with granitoid intrusions. The samples are of quartz metawacke or calcareous quartz metawacke and contain variable amounts (up to 35\%) of spessartine garnet. Samples are from either within or very close to the manganiferous unit of the GHT, as interpreted by MacInnis (1986).

\section{SULPHIDE MINERALOGY AND TEXTURES}

Table 1 is a summary of sulphide mineral abundances in the samples examined in this study. Pyrrhotite is by far the most abundant sulphide mineral and varies from approximately 1 to $15 \%$. In samples not affected by contact metamorphism, pyrrhotite is typically elongate in the plane of cleavage, forming a well defined mineral lineation, and ranges in length from less than $1 \mathrm{~mm}$ up to $1 \mathrm{~cm}$ (Fig. 3A,B). In contact metamorphosed samples, pyrrhotite is typically much smaller (less than $2 \mathrm{~mm}$ in length) and is more commonly disseminated throughout the matrix. A pyrrhotite mineral lineation is evident in some places (Fig. 3C,D). In the samples from Eastville examined in this study, pyrrhotite occurs in two textures. One occurrence is mainly massive but confined to individual beds and fills spaces between garnet grains 
Table 1. Abundance of sulphide minerals.

\begin{tabular}{llllllll} 
Sample Site & Sample Number & Po & Py & Cpy & Aspy & Spl & Ma \\
\hline Halifax & & & & & & & \\
Halifax & CR-95-001 & A & & M & & & \\
Halifax & CR-95-002 & A & M & M & & & \\
& CR-95-003 & A & & M & & & \\
Mount Uniacke & CR-95-004 & A & C & M & & & \\
Mount Uniacke & CR-95-005 & M & C & M & & & \\
Mount Uniacke & CR-95-006 & A & & M & M & & \\
& & & & & & & \\
Beaverbank Highway & CR-95-007 & A & C & M & M & & \\
Beaverbank Highway & CR-95-008 & A & C & M & & M & M \\
Beaverbank Highway & CR-95-009 & A & & M & & & \\
Beaverbank Highway & CR-95-010 & A & C & M & & & M \\
& & & & & & & \\
Eastville & CR-95-011 & A & M & M & & & \\
Eastville & CR-95-012 & A & M & M & & & \\
Eastville & CR-95-014 & A & M & M & & & \\
Eastville & CR-95-016 & A & M & M & M & & \\
Eastville & CR-95-017 & A & C & & & & \\
& & & & & & & \\
\hline
\end{tabular}

Po = pyrrhotite Py = pyrite $;$ Cpy = chalcopyrite Aspy = arsenopyrite $; \mathrm{Spl}=$ sphalerite; $\mathrm{Ma}=$ marcasite

$\mathrm{A}=$ abundant $(>5 \%) ; \mathrm{C}=$ common $(1-5 \%) ; \mathrm{M}=\operatorname{minor}(<1 \%)$

(Fig. 3E). The other occurrence consists of tiny $(<0.5 \mathrm{~mm})$ pyrrhotite grains in the center of individual garnet porphyroblasts, or larger pyrrhotite aggregates surrounded by aggregates of garnet. The latter texture is common in Mn-rich layers of the GHT in the Meguma Group and was also observed in sample CR-95-009 in the Beaverbank Highway site (Fig. 3F; see also Feetham et al., 1997). More detailed studies of pyrrhotite mineralogy and texture at Eastville were presented by Jenner (1982) and Binney et al. (1986).

Alteration of pyrrhotite to marcasite (and/or pyrite?) occurs in several of the samples from the Beaverbank Highway site (Fig. 3G) and appears to be confined to rocks with well developed cleavage (see also Haysom et al., 1997). This type of replacement texture has been described in mine tailings (Jambor, 1994) and is common in the formation of "birds eye" textures (Ramdohr, 1969). The new mineral formed in the replacement texture is commonly called marcasite but according to Ramdohr (1969), pyrite either coexists or is the only secondary mineral present. Replacement rims of ilmenite and/or rutile (anatase?) are very common around pyrrhotite and occur in nearly all samples. Also in virtually all samples, pyrrhotite crystals contain abundant inclusions of silicate, oxide and other sulphide minerals. In several cases, inclusion trails are aligned and curved parallel to the cleavage direction; in other samples, the inclusions are entirely random. The curved inclusion trails appear to be confined to low grade, regionally metamorphosed rocks such as at the Beaverbank Highway site and have been observed also in samples taken at the HIA (unpublished data).

Pyrite is the next most abundant sulphide mineral, comprising less than $5 \%$ of all samples. It commonly occurs as large ( $0.5 \mathrm{~cm}$ or more across) euhedral grains with sharp crystal edges (Fig. 3H). Inclusions in these crystals are much less abundant than in pyrrhotite. Marcasite (and/or pyrite?)

Fig. 3 (next two pages). Photomicrographs of various sulphide mineral assemblages. (A) Sample CR-95-008, Beaverbank Highway site, reflected light. Pyrrhotite (po) with long axis parallel to cleavage plane. Scale bar represents $0.62 \mathrm{~mm}$. (B) Same as A but plane polarized light, crossed nicols. (C) Sample CR-95-003, Halifax site, reflected light. Fine grained pyrrhotite (po) in contact metamorphic aureole of the South Mountain Batholith. Scale bar represents $0.62 \mathrm{~mm}$. (D) Same as C but plane polarized light, crossed nicols. Andalusite (AND) and cordierite (CRD) porphyroblasts are common. (E) Sample CR-05-011, Eastville site, reflected light. Pyrrhotite (po) fills space between garnet (gnt) porphyroblasts. Scale bar represents $0.62 \mathrm{~mm}$. (F) Sample CR-95-009, Beaverbank Highway site, reflected light. Aggregate of pyrrhotite (po) rimmed by aggregates of spessartine garnets (gnt). This is a common feature of coticules in the GHT throughout the Meguma Group. Scale bar represents $0.16 \mathrm{~mm}$. (G) Sample CR-95-010, Beaverbank Highway site, reflected light. Pyrrhotite (po) rimmed by marcasite (ma) and/or pyrite?. Scale bar represents $0.62 \mathrm{~mm}$. (H) CR-95007, Beaverbank Highway site, reflected light. Euhedral pyrite (py) associated with anhedral pyrrhotite (po). Scale bar represents $0.62 \mathrm{~mm}$. 

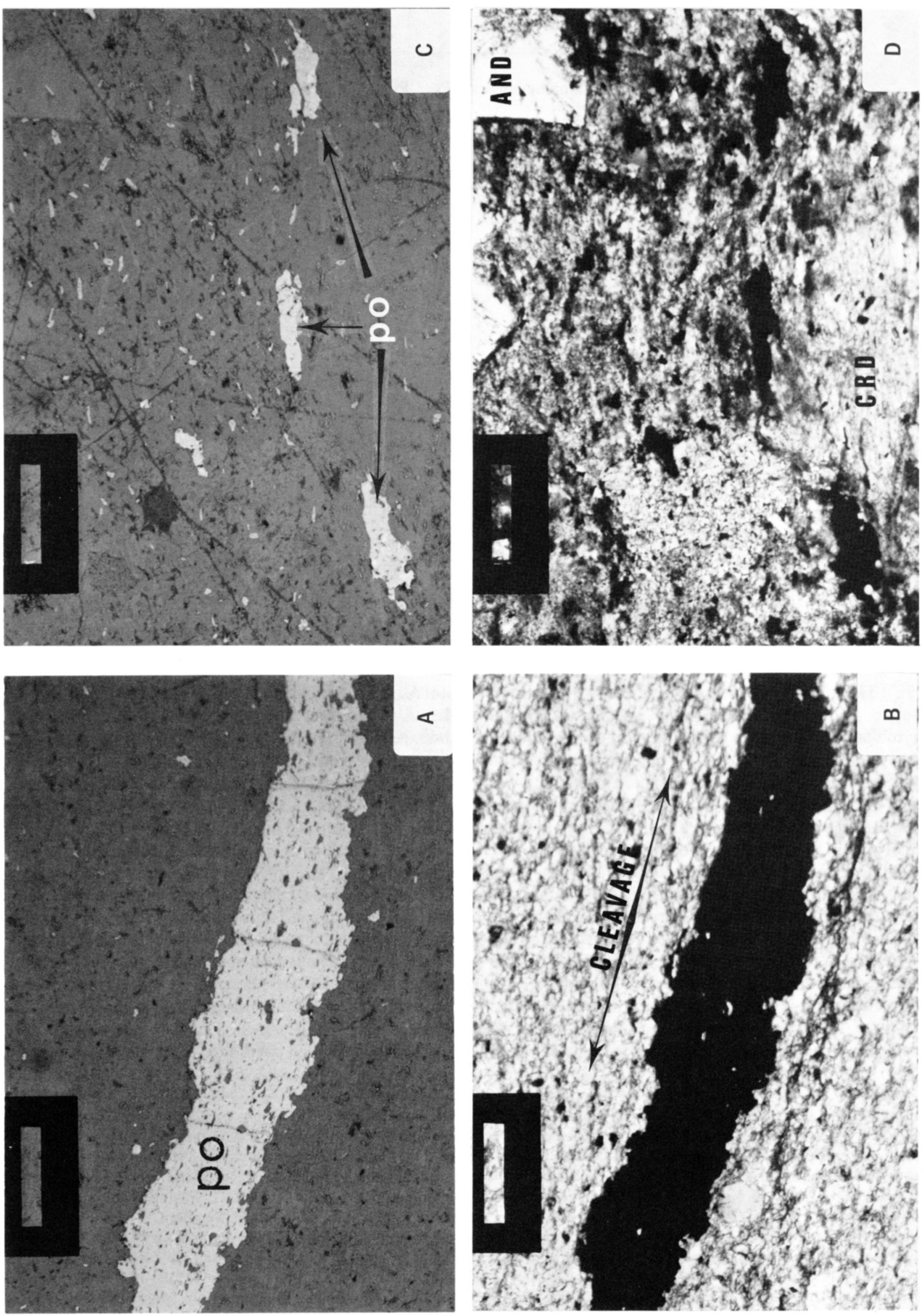

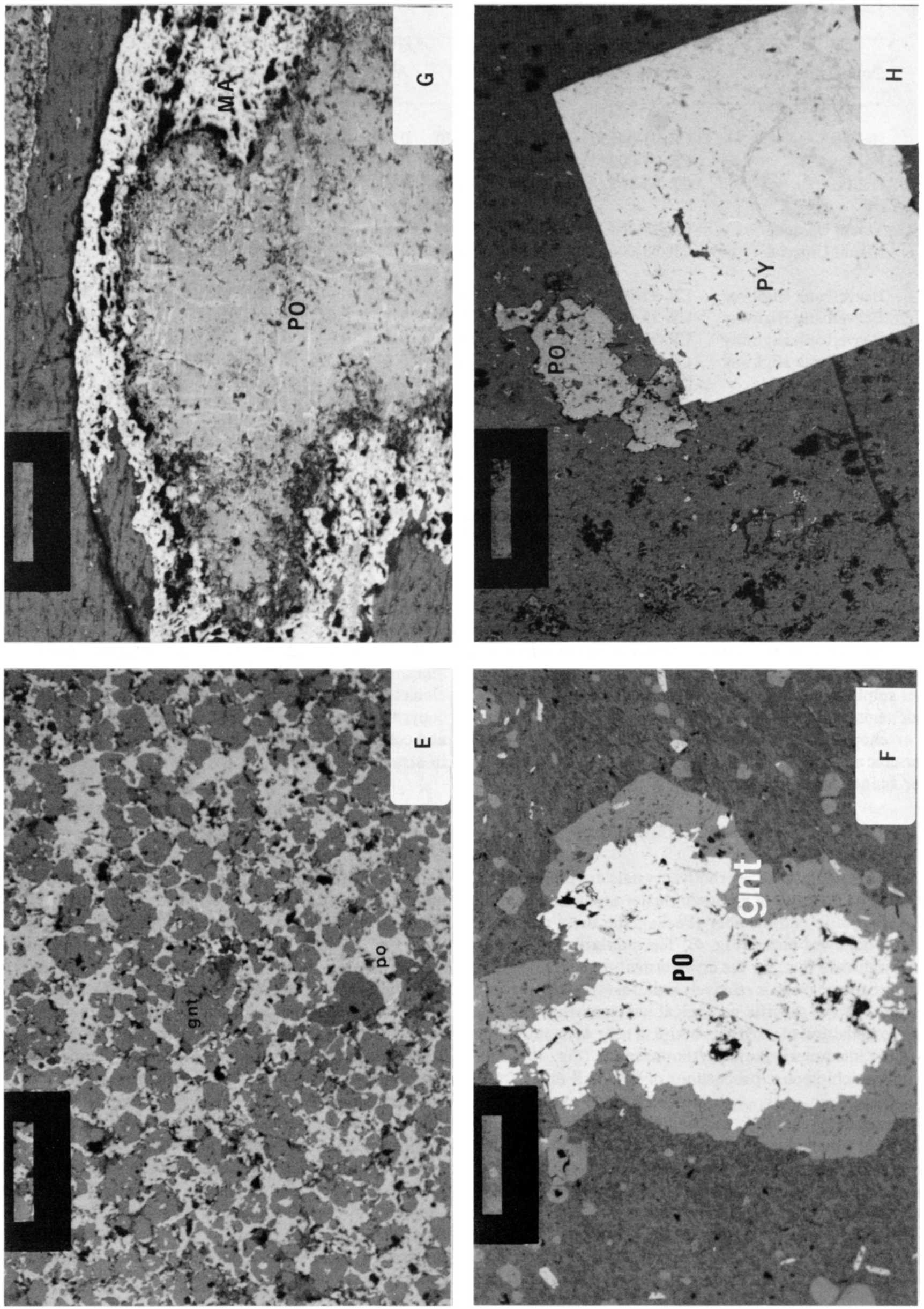
Table 2. Pyrrhotite compositions (wt.\%)*.

\begin{tabular}{llllllllll}
\hline Sample Site & Sample Number & Fe & S & As & Ni & Co & Total & Fe** & S $^{* *}$ \\
& & & & & & & & & \\
\hline & & & & & & & & & \\
Halifax & CR-95-001 (2) & 59.49 & 38.70 & 0.24 & 0.03 & 0.24 & 98.97 & 7.062 & 8.000 \\
Halifax & CR-95-002 (1) & 59.76 & 38.01 & 0.32 & 0.35 & 0.40 & 98.89 & 7.224 & 8.000 \\
Halifax & CR-95-003 (2) & 59.14 & 38.60 & 0.21 & 0.13 & 0.29 & 98.53 & 7.038 & 8.000 \\
& & & & & & & & & \\
Mount Uniacke & CR-95-004 (5) & 60.00 & 39.83 & 0.19 & 0.07 & 0.20 & 100.43 & 6.920 & 8.000 \\
Mount Uniacke & CR-95-006 (2) & 59.75 & 38.66 & 0.22 & 0.05 & 0.22 & 99.01 & 7.100 & 8.000 \\
& & & & & & & & & \\
Beaverbank Highway & CR-95-007(3) & 60.37 & 39.24 & 0.25 & 0.05 & 0.30 & 100.34 & 7.067 & 8.000 \\
Beaverbank Highway & CR-95-008 (2) & 61.08 & 39.20 & 0.40 & 0.02 & 0.05 & 100.89 & 7.157 & 8.000 \\
Beaverbank Highway & CR-95-009 (2) & 59.03 & 38.74 & 0.23 & 0.38 & 0.24 & 98.96 & 7.000 & 8.000 \\
Beaverbank Highway & CR-95-010(7) & 60.05 & 39.70 & 0.24 & 0.05 & 0.19 & 100.42 & 6.949 & 8.000 \\
& & & & & & & & & \\
Eastville & CR-95-011 (6) & 60.11 & 39.94 & 0.20 & 0.18 & 0.32 & 100.91 & 6.912 & 8.000 \\
Eastville & CR-95-012(5) & 60.00 & 39.88 & 0.22 & 0.06 & 0.27 & 100.51 & 6.912 & 8.000 \\
Eastville & CR-95-014(5) & 59.54 & 39.94 & 0.28 & 0.19 & 0.20 & 100.29 & 6.848 & 8.000 \\
& & & & & & & & & \\
\hline
\end{tabular}

*Values are averages. Number of analyses given in parentheses.

* The two last columns for Fe and $\mathrm{S}$ represent atomic proportions in the formula of pyrrhotite.

is a minor component and was observed only in samples CR-95-008 and CR-95-010. Marcasite rims pyrrhotite in both cases forming a replacement texture (see above). The secondary marcasite in this texture contains abundant inclusions and is anhedral, with embayed or corroded crystal edges. Other sulphide minerals that are common but occur in only minor amounts (less than 1\%) include chalcopyrite, sphalerite and arsenopyrite. In addition, sample CR-95-006 contains the arsenic mineral, löllingite ( $\left.\mathrm{FeAs}_{2}\right)$. Typically, these minerals occur as inclusions in pyrrhotite.

\section{SULPHIDE MINERAL CHEMISTRY}

Average analyses of pyrrhotite crystals are presented in Table 2. The majority of analyses cluster around the monoclinic pyrrhotite end-member $\left(\mathrm{Fe}_{7} \mathrm{~S}_{8}\right)$, the most magnetic and iron-deficient phase (Fig. 4). The similarity in compositions indicates that, for the crystals analyzed in this study, pyrrhotite composition is relatively uniform (monoclinic type) regardless of the specific geological environment. The average composition of most pyrrhotite is near 46.5 atomic \% $\mathrm{Fe}$, in the ideal monoclinic pyrrhotite range (Fig. 4b). The average stoichiometric proportions of $\mathrm{Fe}$ and $\mathrm{S}$ range from $\mathrm{Fe}_{6.912} \mathrm{~S}_{8.000}$ to $\mathrm{Fe}_{7.224} \mathrm{~S}_{8.000}$ (Table 2). These values are similar to analyses of pyrrhotite from samples from drill core taken at the HIA, which cluster around 46.5 atomic \% Fe (Fig. 5). The average stoichiometry of pyrrhotite from the HIA site was calculated to be $\mathrm{Fe}_{7.058} \mathrm{~S}_{8.000}$, indicative of monoclinic pyrrhotite (Pasava et al., 1995).

Trace element contents in pyrrhotite (Table 2) are mostly below or very close to detection limits; however, some pyrrhotite contains significant concentrations of arsenic, nickel and cobalt. Although only in trace amounts, these elements may have environmental implications considering the relatively high rate of reactivity of pyrrhotite compared to some of the other sulphide minerals such as pyrite, arsenopyrite and sphalerite (e.g., Jambor, 1994; Nicholson, 1994). Trace element contents are also given for pyrite, arsenopyrite, chalcopyrite and sphalerite (Table 3 ), and indicate that arsenic and cobalt are significant in pyrite and cobalt is significant in arsenopyrite.

\section{X-RAY DIFFRACTION ANALYSES}

Stoichiometric pyrrhotite (troilite) contains equal proportions of iron and sulphur and is represented by the formula FeS (or $\mathrm{Fe}_{8} \mathrm{~S}_{8}$ ). However, most pyrrhotite in nature is iron-deficient and can be expressed by the simplified formula $\mathrm{Fe}_{1-\mathrm{x}} \mathrm{S}$ where $\mathrm{x}$ ranges from 0.0 to 0.125 (i.e., compositions from $\mathrm{Fe}_{8} \mathrm{~S}_{8}$ to $\mathrm{Fe}_{7} \mathrm{~S}_{8}$ ). Troilite is non-magnetic and relatively rare, occurring mostly in meteorites, but it has been described in some sulphide ores from various localities throughout the world (e.g., Carpenter and Desborough, 1964; Lianxing and Vokes, 1996). The structure of troilite is hexagonal and is a derivative structure of the NiAs mineral nickeline (Wuensch, 1974). All pyrrhotite minerals are considered to be derivatives of the NiAs structure through , suppression of the symmetry operation translation (Wuensch, 1974). This situation leads to larger-than-normal unit cells called superstructures. Because of the range of Fe-deficiency (non-stoichiometry) for most pyrrhotite minerals, a variety of superstructures are possible, such as $4 \mathrm{C}$ monoclinic, $1 \mathrm{C}$ hexagonal, $5 \mathrm{C}$ hexagonal and $11 \mathrm{C}$ orthorhombic (e.g., Carpenter and Desborough, 1964; Fleet, 1971; Craig and Scott, 


\section{Composition of Pyrrhotite (This Study) \\ Number of Analyses $=42$}
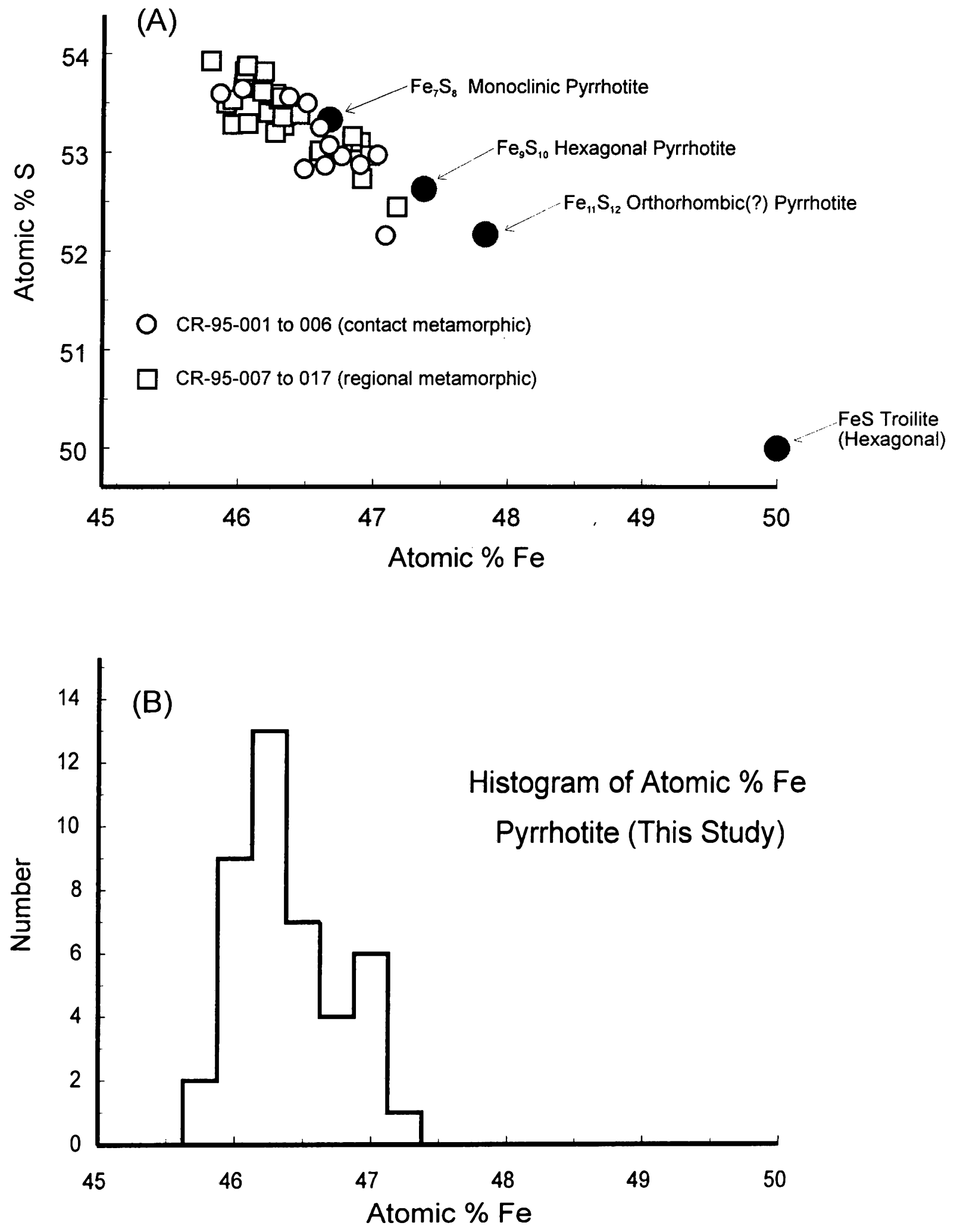

Fig. 4. (A) Plot of atomic \% S against atomic \% Fe for pyrrhotite analyzed in this study. Several ideal pyrrhotite compositions are plotted for reference (structural types from Craig and Scott, 1974). Most pyrrhotite clusters around monoclinic Fe ${ }_{7} S_{8}$. (B) A histogram showing that the majority of crystals contain between 46 and 47 atomic \% Fe. 


\section{Composition of Pyrrhotite (HIA) Number of Analyses $=38$}
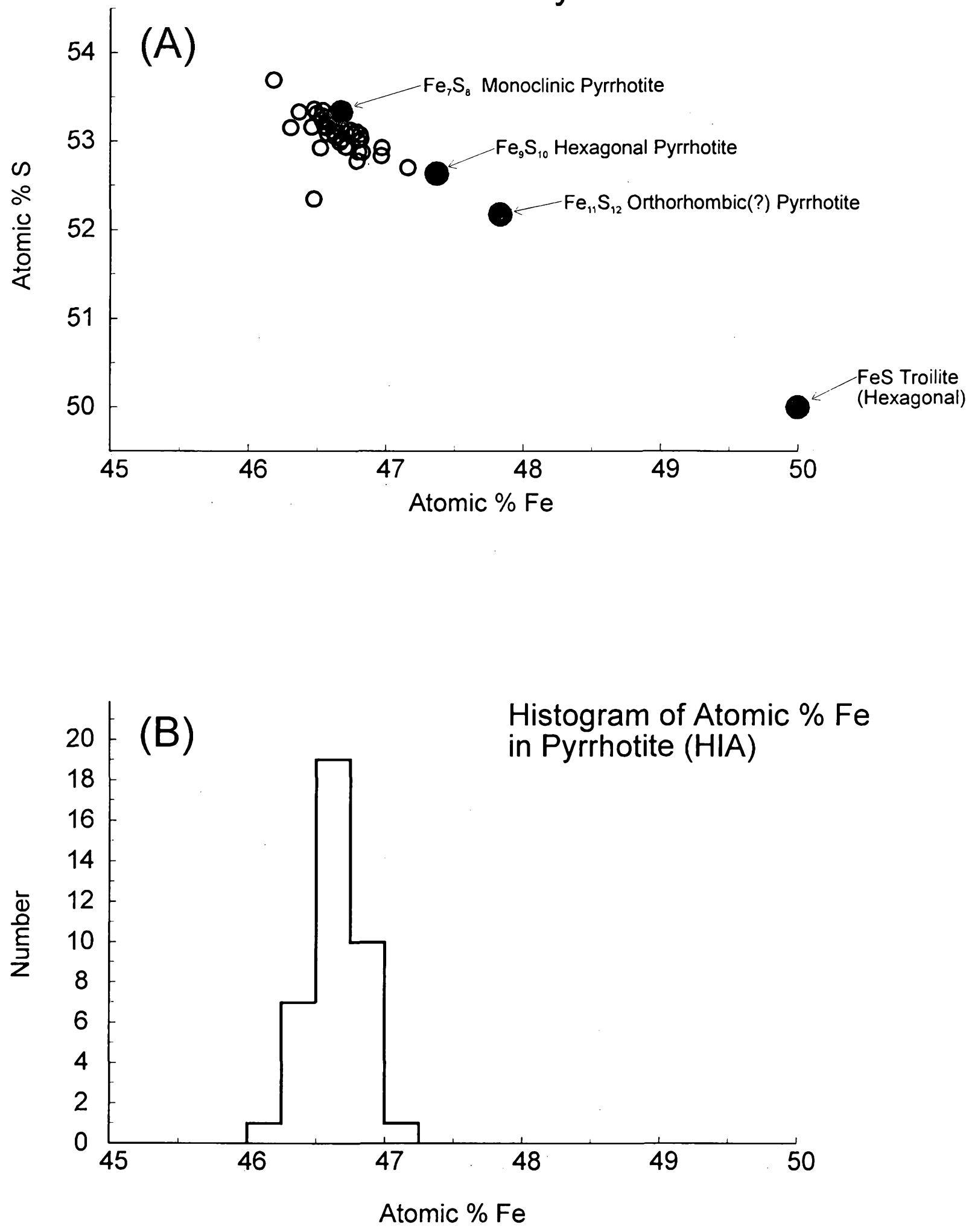

Fig. 5. (A) Plot of atomic \% S against atomic \% Fe for pyrrhotite crystals from drill core taken at the Halifax International Airport (data from Knee, 1995). The majority of pyrrhotite is monoclinic $\mathrm{Fe}_{7} \mathrm{~S}_{8}$. (B) Histogram showing that the majority of crystals contain between 46 and 47 atomic \% Fe. 
Table 3. Pyrite, arsenopyrite, chalcopyrite, and sphalerite compositions (wt.\%)*.

\begin{tabular}{|c|c|c|c|c|c|c|c|c|c|c|c|}
\hline Mineral & Sample Site & Sample Number & $\mathrm{Fe}$ & $\mathbf{S}$ & As & $\mathrm{Zn}$ & $\mathrm{Cu}$ & $\mathrm{Ni}$ & Co & $\mathrm{Ti}$ & Total \\
\hline pyrite & Mount Uniacke & CR-95-004 (3) & 46.53 & 52.21 & 0.26 & 0.07 & 0.04 & 0.23 & 0.26 & 0.00 & 99.61 \\
\hline pyrite & Mount Uniacke & CR-95-005 (1) & 46.53 & 53.28 & 0.24 & 0.19 & 0.01 & 0.17 & 0.19 & 0.08 & 100.72 \\
\hline pyrite & Beaverbank Highway & CR-95-007 (5) & 46.68 & 52.75 & 0.48 & 0.09 & 0.01 & 0.09 & 0.17 & 0.00 & 100.28 \\
\hline pyrite & Beaverbank Highway & CR-95-008 (2) & 47.21 & 53.52 & 0.66 & 0.19 & 0.06 & 0.00 & 0.14 & 0.00 & 101.81 \\
\hline pyrite & Beaverbank Highway & CR-95-010 (6) & 46.54 & 53.31 & 0.26 & 0.10 & 0.02 & 0.05 & 0.15 & 0.00 & 100.44 \\
\hline pyrite & Eastville & CR-95-014 (1) & 46.18 & 52.76 & 0.33 & 0.21 & 0.00 & 0.10 & 0.22 & 0.00 & 99.79 \\
\hline arsenopyrite & Mount Uniacke & CR-95-006 (2) & 31.89 & 16.86 & 48.22 & 0.00 & 0.07 & 0.10 & 1.57 & 0.01 & 98.73 \\
\hline arsenopyrite & Beaverbank Highway & CR-95-007 (1) & 34.79 & 20.34 & 44.34 & 0.05 & 0.00 & 0.00 & 0.27 & 0.00 & 99.79 \\
\hline chalcopyrite & Mount Uniacke & CR-95-006 (1) & 30.06 & 33.92 & 0.07 & 0.01 & 36.28 & 0.00 & 0.00 & 0.01 & 100.34 \\
\hline chalcopyrite & Beaverbank Highway & CR-95-008 (3) & 30.81 & 34.44 & 0.07 & 0.03 & 36.66 & 0.00 & 0.07 & 0.03 & 102.11 \\
\hline chalcopyrite & Beaverbank Highway & CR-95-009 (1) & 30.51 & 34.14 & 0.10 & 0.27 & 36.34 & 0.03 & 0.21 & 0.01 & 101.63 \\
\hline chalcopyrite & Beaverbank Highway & CR-95-010 (2) & 30.72 & 34.69 & 0.10 & 0.14 & 35.66 & 0.00 & 0.01 & 0.00 & 101.34 \\
\hline sphalerite & Beaverbank Highway & CR-95-008 (3) & 5.65 & 29.30 & 0.00 & 57.18 & 0.49 & 0.03 & 0.07 & 4.43 & 97.14 \\
\hline
\end{tabular}

*Values are averages. Number of analyses given in parentheses.

1974; Morimoto et al., 1975). For the purposes of this study, the traditional classification of hexagonal and monoclinic structural types (Arnold, 1967; Vaughan and Craig, 1978) is used.

$\mathrm{X}$-ray diffraction powder peaks in the $50^{\circ}$ to $52^{\circ} 2 \theta$ range ( $\operatorname{Co} \mathrm{K} \alpha$ ) can be used to determine the pyrrhotite structural state (Arnold, 1966, 1969). Two closely spaced reflections of approximately equal intensity are indicative of monoclinic pyrrhotite, whereas a single peak indicates hexagonal pyrrhotite (Vaughan and Craig, 1978). Arnold (1966) showed that for double-peak profiles, increasing intensity of the lower $2 \theta$ peak corresponds to an increase in the abundance of hexagonal pyrrhotite in monoclinic-hexagonal mixtures.

Five samples of pyrrhotite from this study were analysed by the X-ray diffraction powder method (Fig. 6). All five samples show near-equal intensity double peaks, indicating that the majority of the pyrrhotite has monoclinic structure. However, double-peak intensities in the same sample vary slightly. Samples CR-95-003 and CR-95-006 show a more intense lower (left side) $2 \theta$ peak, possibly reflecting a minor component of hexagonal pyrrhotite. The other samples (CR-95-001, CR-95-007 and CR-95-011) show more intense higher (right side) $2 \theta$ peaks. This is consistent with so-called "anomalous" pyrrhotite described by Clark (1966). Little is known about "anomalous" pyrrhotite in terms of its stability field but it is apparently common in low-temperature, sedimentary environments. Like hexagonal pyrrhotite, it is considered to be antiferromagnetic but may have a triclinic(?) structure (Clark, 1966). Taylor (1971) has shown that one possible way in which anomalous pyrrhotite forms is by oxidation of hexagonal pyrrhotite, although he also indicated that it has been described as forming borders or rims on monoclinic pyrrhotite.

The XRD analyses presented here suggest that the main pyrrhotite type is monoclinic $\mathrm{Fe}_{7} \mathrm{~S}_{8}$. This is consistent with results from microprobe analyses presented above although some variations in $\mathrm{Fe}$ and $\mathrm{S}$ proportions occur. Hexagonal pyrrhotite may be present in minor amounts and anomalous pyrrhotite may occur, but more detailed work needs to be done to further validate this little-known pyrrhotite type. In terms of chemical behaviour and ARD development, the distinction between monoclinic and anomalous pyrrhotite types may not be significant, as the proportions of $\mathrm{Fe}$ and $\mathrm{S}$ are very similar.

\section{Discussion}

The data and observations presented above have important implications for understanding the processes involved in the production of ARD from Halifax Formation rocks. Firstly, identification of the major sulphide minerals in the Halifax Formation, including the abundance and regional distribution of monoclinic pyrrhotite $\left(\mathrm{Fe}_{7} \mathrm{~S}_{8}\right)$ is of fundamental importance. The higher reactivity of pyrrhotite compared to pyrite (and most other sulphide minerals) makes its proper identification essential. In simple terms, high reactivity and an abundance of pyrrhotite lead to high production of ARD under the right oxidizing conditions. This is especially true in the initial stages of ARD development. The pyrrhotite examined in this study appears to be almost purely monoclinic, with only minor amounts of hexagonal and possibly anomalous pyrrhotite types. The monoclinic variety may be 


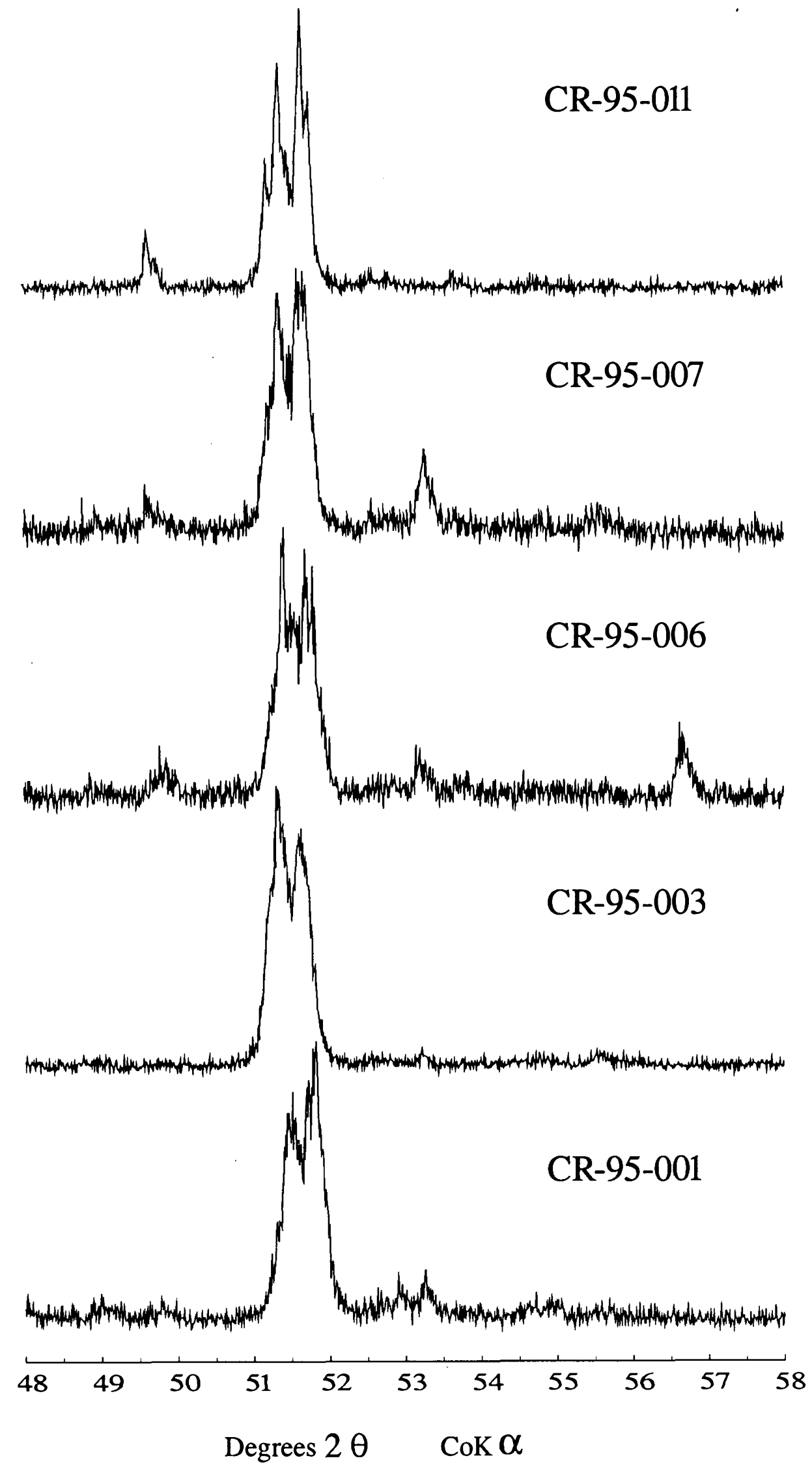

Fig. 6. Powder XRD diffractograms for five representative samples from this study. All patterns show double peaks indicative of monoclinic $\mathrm{Fe}_{7} \mathrm{~S}_{8}$. See text for further discussion. 
the fastest to oxidize and will theoretically contribute the maximum amount of acidity compared to other pyrrhotite forms. Oxidation tests are currently in progress to test these hypotheses and it should be emphasised that actual oxidation kinetics under field conditions can be assessed only on a site-specific basis.

Secondly, mineral texture is an important factor. In regionally metamorphosed (greenschist facies) areas of the Halifax Formation, pyrrhotite is commonly coarse grained and occurs along cleavage planes. When these rocks are disrupted by activities such as construction or quarrying, they tend to break naturally along the cleavage planes, exposing an increased amount of pyrrhotite to oxidation processes. Such activities may also result in grain size reduction of pyrrhotite. Grain size reduction may also lead to increased oxidation rates by exposing larger surface areas of the pyrrhotite crystals. Natural weathering processes may also lead to increased pyrrhotite oxidation because of the easy access of fluids to pyrrhotite surfaces by fluid migration along cleavage planes.

In contact metamorphosed rocks, pyrrhotite texture is quite different. Pyrrhotite is finer grained and evenly disseminated throughout the matrix. The smaller grain size means higher surface area but fluid access to crystal surfaces is limited because cleavage is not well developed. Consequently, ARD development in these areas may be less significant than in regionally metamorphosed areas but this has to be assessed on a site specific basis. For example, this may be the case under natural weathering conditions as in a roadside outcrop. However, these textural observations may be less important in a tailings environment where all grains are reduced to silt-size particles.

The pyrite observed in this study is typically euhedral with sharp crystal edges and does not form along cleavage planes. Jones and Fox (1997) and Jones (1997) have determined that euhedral pyrite is considerably resistant to oxidative dissolution under acidic conditions (over a six week period). Under natural field conditions, given its relative resistance to oxidation and its textural features, pyrite may not pose as significant a risk as pyrrhotite, especially in the short term. Secondary marcasite (and/or pyrite?) replaces pyrrhotite and has only been observed in the low grade, greenschist facies rocks. The marcasite is anhedral with highly corroded crystal edges, occurs along cleavage planes, and would therefore be easily accessible to fluids. The other sulphide minerals (chalcopyrite, arsenopyrite, and sphalerite) typically occur as inclusions in pyrrhotite crystals and it is possible that they are galvanically protected from oxidation.

Thirdly, in addition to sulphide mineral identification and texture, trace element abundances are also important. Arsenic, for example, will not be released from arsenopyrite if that mineral is not reactive. Trace amounts of arsenic in pyrrhotite, however, may easily be released into the surrounding environment considering that pyrrhotite is highly reactive. As presented above, pyrrhotite can also contain detectable concentrations of $\mathrm{Ni}$ and $\mathrm{Co}$. These elements have been found in very high concentrations, for example, in pore water (Ni: 181-188 mg/L; Co: $93-105 \mathrm{mg} / \mathrm{L}$ ) and seepage
(Ni: $23-43 \mathrm{mg} / \mathrm{L}$; Co: $4.5-9.8 \mathrm{mg} / \mathrm{L}$ ) from the waste rock pile at the HIA (Lund et al., 1987). These observations suggest that pyrrhotite is a contributor to the ARD problem at the HIA and an understanding of that mineral should be a part of any remediation effort, as well as future planning processes.

ARD from the Halifax Formation has been, and continues to be, a very expensive environmental problem in Nova Scotia. Sulphide-rich rocks are widespread throughout the province and avoidance is difficult, especially for large scale construction projects such as highway development, municipal expansion, or any other projects that require disruption of the bedrock. For example, the entire city of Halifax is underlain by the Halifax Formation and avoidance is impossible. Mineralogical and geological research such as this study is fundamental to the understanding of ARD development, and through this type of approach successful remediation efforts may be applied. ARD problems are unlikely to be fixed if it is not understood how they developed in the first place. Predicting which rocks and areas are susceptible to ARD can be accomplished through a thorough understanding of the mineralogy.

\section{Conclusions}

The predominant sulphide mineral in the samples from the Halifax Formation examined in this study is pyrrhotite. Also present, in lesser amounts, are pyrite, marcasite, chalcopyrite, arsenopyrite and sphalerite. Microprobe data indicate that the pyrrhotite is the monoclinic variety $\left(\mathrm{Fe}_{7} \mathrm{~S}_{8}\right)$. The compositions of all pyrrhotite crystals probed are between 45.5 and 47.5 atomic \% Fe, in the ideal monoclinic pyrrhotite range. Data from pyrrhotite in drill core samples from the Halifax International Airport overlap with the data from this study.

XRD analyses of pyrrhotite from five samples show typical, almost equal intensity double peaks, indicative of monoclinic pyrrhotite. These data confirm the results of the microprobe work. Comparisons of pyrrhotite compositions among samples taken from different geological settings (i.e., within and outside the contact metamorphic aureoles of granitic intrusions) suggest there is little to no regional variation in pyrrhotite composition.

This study confirms a risk of ARD is present throughout the Halifax Formation. Whether or not ARD actually occurs depends on numerous factors and can only be assessed on a site-specific basis. Thorough sampling and accurate testing to predict ARD potential, including detailed mineralogical studies, are an essential step in landuse planning throughout the Halifax Formation.

\section{ACKnowledgements}

This work results from a B.Sc. Honours thesis by the second author (C. Robinson) and forms part of a Ph.D. study currently in progress by the first author (D. Fox) at the Department of Earth Sciences, Dalhousie University. Both theses are supervised by M. Zentilli. We wish to thank Gordon Brown 
for thin section preparation and Robert MacKay for assistance with the microprobe. Milton Graves has always been a constant source of input into the ARD study group at Dalhousie University. Sandy Grist donated his time and expertise in lab procedures to help in this research. Appreciation is extended to J.A. Colwell for reviewing the initial manuscript. An anonymous reviewer is thanked for a thorough and constructive critique which helped to clarify several points in the text. R. Jones helped in the editing process. Funding was provided by research grants to the Fission Track Laboratory at Dalhousie University.

ARNolD, R.G. 1966. Mixtures of hexagonal and monoclinic pyrrhotite and the measurement of the metal content of pyrrhotite by X-ray diffraction. American Mineralogist, 51, pp. 1221-1227.

-.-- 1967. Range in composition and structure of 82 natural terrestrial pyrrhotites. Canadian Mineralogist, 9, pp. 31-50.

-.--- 1969. Pyrrhotite phase relations below $304 \pm 6^{\circ} \mathrm{C}$ at $<1$ atm total pressure. Economic Geology, 64, pp. 405-419.

Bhatti, T.M., Bigham, J.M., Carlson, L., and Tuovinen, O.H. 1993. Mineral products of pyrrhotite oxidation by Thiobacillus ferrooxidans. Applied and Environmental Microbiology, 59(6), pp. 1984-1990.

Binney, W.R., Jenner, K.A., Sangster, A.L., and Zentilli, M. 1986. A stratabound zinc-lead deposit in Meguma Group metasediments at Eastville, Nova Scotia. Maritime Sediments and Atlantic Geology, 22, pp. 65-88.

CARPENTER, R.H. and Desborough, B.A. 1964. Range in solid solution and structure of naturally occurring troilite and pyrrhotite. American Mineralogist, 49, pp. 1350-1365.

CLARK, A.H. 1966. Stability field of monoclinic pyrrhotite. Transactions of the Institution of Mining and Metallurgy, Section B, 75, pp. 232-235.

CRAIG, J.R. and Scott, S.D. 1974. Sulphide phase equilibria (Chapter 5). In Reviews in Mineralogy, Volume 1, Sulphide Mineralogy. Mineralogical Society of America, pp. CS1-CS110.

ENVIRONMENT Act S.N.S. 1994-95, c. 1, section 66. Order in Council 95-296 (April 11, 1995), N.S. Reg. 57/95, 7 p.

Fairbairn, H.W., Hurley, P.M., Pinson, W.H., and Cormier, R.F. 1960. Age of granitic rocks of Nova Scotia. Bulletin of the Geological Society of America, 71, pp. 399-414.

Feetham, M., Ryan, R.J., Pe-Piper, G., and O'Beirne-Ryan, A.M. 1997. Lithogeochemical characterization of the Beaverbank unit of the Halifax Formation, Meguma Group, and acid drainage implications. Atlantic Geology, 33, pp. 133-141.

FLEET, M.E. 1971. The crystal structure of a pyrrhotite $\left(\mathrm{Fe}_{7} \mathrm{~S}_{8}\right)$. Acta Crystallography, B27, pp. 1864-1867.

Graves, M.C. and Zentilli, M. 1988. The lithochemistry of metalenriched coticules in the Goldenville-Halifax transition zone of the Meguma Group, Nova Scotia. Current Research, Part B, Geological Survey of Canada, Paper 88-1B, pp. 251-261.

HAYsom, S.J., Horne, R., and PE-PIPER, G. 1997. The opaque mineralogy of metasedimentary rocks of the Meguma Group, BeaverbankRawdon area, Nova Scotia. Atlantic Geology, 33, pp. 105120.

Henderson, J.R., Wright, T.O., and Henderson, M.N. 1986. A history of cleavage and folding: An example from the Goldenville Formation, Nova Scotia. Geological Society of America Bulletin, 97, pp. 1354-1366.

Hennigar, T.W. and GibB, J.E. 1987. Surface and groundwater impacts of acid mine drainage from the Meguma slates of
Nova Scotia. Proceedings, Acid Mine Drainage Seminar/ Workshop, Halifax, Nova Scotia, March 23-26, 1987. Environment Canada, pp. 165-187.

Jacques, Whitford AND Associates Limited. 1990. Acidic Slate Assessment, Highway 107 Construction, Petpeswick Lake, Halifax County. Unpublished Consultant Study for the Nova Scotia Department of the Environment, Draft Report, March 23, 1990, 63 p.

JANZen, M.P., Nicholson, R.V., and SchareR, J.M. 1997. The role of enhanced particle surface area, crystal structure and trace metal content on pyrrhotite oxidation rates in tailings. In Fourth International Conference on Acid Rock Drainage, Volume 1, pp. 401-415.

JAMBOR, J.L. 1994. Mineralogy of sulfide-rich tailings and their oxidation products. In The Environmental Geochemistry of Sulphide Mine-wastes. Short Course Handbook, Mineralogical Association of Canada, 22, pp. 59-102.

JENNER, K. 1982. A study of sulphide mineralization in Gold Brook, Colchester County, Nova Scotia. B.Sc. Honours thesis, Dalhousie University, Halifax, Nova Scotia.

Jones, C.F., LeCount, S., Smart, R.S.C., and White, T.J. 1992. Compositional and structural alteration of pyrrhotite surfaces in solution: XPS and XRD studies. Applied Surface Science, 55, pp. 65-85.

JoNes, R.A. 1997. Relative chemical and biological oxidation of sulphides in the Meguma Supergroup, Nova Scotia: the role of mineralogy, texture and composition. B.Sc. Honours thesis, Dalhousie University, Halifax, Nova Scotia, 103 p.

Jones, R.A. and Fox, D. 1997. Relative chemical and biological oxidation of sulphides in the Meguma Supergroup, Nova Scotia: the role of mineralogy, texture and composition. Atlantic Geology, 33, p. 64.

KePpie, J.D. 1979a. Geological map of Nova Scotia. Nova Scotia Department of Mines and Energy.

...-. 1979b. Structural map of Nova Scotia. Nova Scotia Department of Mines and Energy.

Keppie, J.D. and Muecke, G.M. 1979. Metamorphic map of Nova Scotia. Nova Scotia Department of Mines and Energy.

Kerekes, J., Freedman, B., Howell, G., and Clifford, P. 1984. Comparison of the characteristics of an acidic eutrophic, and an acidic oligotrophic lake near Halifax, Nova Scotia. Water Pollution Research Journal of Canada, 15(4), pp. 1 9.

KING, M. 1985. Acid drainage and the acidification of Nova Scotia waters. Environment Canada Report, 38 p.

KING, M.S. 1997. Magnetic susceptibility mapping: applications for the Meguma Group, central Nova Scotia. Atlantic Geology, 33, pp. 121-131.

KNEE, K. 1995. Magnetic susceptibility of Halifax Formation Slates at the Halifax International Airport: correlation with potential for acid drainage. B.Sc. Honours thesis, Dalhousie University, Halifax, Nova Scotia, 45 p.

KwONG, Y.T.J. and LAWRENCE, J.R. 1994. Mineralogical controls of sulfide oxidation. National Hydrology Research Institute, Contribution No. 94010,87 p.

LianXing, G. and Vokes, F.M. 1996. Intergrowths of hexagonal and monoclinic pyrrhotites in some sulphide ores from Norway. Mineralogical Magazine, 60, pp. 303-316.

Lund, O.P., Vaughan, J., and Thirumurthi, D. 1987. Impact of acid drainage pollution from mineralized slate at Halifax airport. Water Pollution Resources Journal of Canada, 2(2), pp. 308-325.

MacINNIs, I.N. 1986. Lithogeochemistry of the Goldenville-Halifax transition (GHT) of the Meguma Group in the manganiferous 
zinc-lead deposit at Eastville, Nova Scotia. B.Sc. Honours thesis, Dalhousie University, Halifax, Nova Scotia, 138 p.

Manchester, K. 1986. Survey of quarry pits in the Halifax Formation rocks of southwestern Nova Scotia. Environment Canada Report, 5 p.

McGrath, P.H. 1970. Aeromagnetic interpretation Appalachia, New Brunswick and Nova Scotia (11D, E, F, K; 20 O, P; 21 A, G, H, J). Geological Survey of Canada, Paper 70-1A, pp. 79-82.

Morimoto, N., Gyobu, A., Mukaiyama, H., and Izawa, E. 1975. Crystallography and stability of pyrrhotites. Economic Geology, 70, pp. 824-833.

Mycroft, J.R., Nesbitt, H.W., and Pratt, A.R. 1995. X-ray photoelectron and Auger electron spectroscopy of air oxidized pyrrhotite: distribution of oxidized species with depth. Geochim. Cosmochim. Acta., 59, pp. 721-733.

Natarajan, K.A. 1990. Electrochemical aspects of bioleaching of base-metal sulphides. In Microbial mineral recovery. Edited by H.L. Ehrlich and C.L. Brierley. McGraw-Hill Publishing Company, New York, pp. 79-106.

Nicholson, R.V. 1994. Iron-sulphide oxidation mechanisms: laboratory studies. In The Environmental Geochemistry of Sulphide Mine-wastes. Short Course Handbook, Mineralogical Association of Canada, 22, pp. 163-183.

Nicholson, R.V. and SchareR, J.M. 1994. Laboratory studies of pyrrhotite oxidation kinetics. In Environmental Geochemistry of Sulphide Oxidation. American Chemical Society, Washington D.C., pp. 14-30.

O'Brien, B.H. 1986. Preliminary report on the geology of the Mahone Bay area, Nova Scotia. In Current Research, Part A, Geological Survey of Canada, Paper 86-1A, pp. 439-444.

-...- 1988. A study of the Meguma Terrane in Lunenburg County, Nova Scotia. Geological Survey of Canada, Open File Report $1823,128 \mathrm{p}$.

Pasava, J., Graves, M.C., Macinnis, I.N., and Zentilli, M. 1995. Black slates - A source of acid drainage at the Halifax International Airport, Nova Scotia, Canada. In Mineral Deposits: From their origin to their environmental impacts. Proceedings of the Third Biennial SGA Meeting, Prague, Czech Republic, August 28-31, 1995, pp. 785-788.

Petripas, B. 1979. A statistical evaluation of the effect of acid leachate on water quality, in Union Square, Lunenburg County. Nova Scotia Department of the Environment Report, June, 1979,56 p.

PhILIPS, 1993. X'PERT Installation and user manuals, 7 volumes.

Porter Dillon Limited. 1985. Environmental study of the Salmon River watershed in the vicinity of the Halifax International Airport, Halifax, Nova Scotia. Unpublished Consult Study for Transport Canada, Final Report, April, 1985, pp. 1.112.1.

Pratt, A.R., Nesbitt, H.W., and Mycroft, J.R. 1996. The increased reactivity of pyrrhotite and magnetite phases in sulphide mine tailings. Journal of Geochemical Exploration, 56, pp. 1-11.

RAMDOHR, P. 1969. The ore minerals and their intergrowths. Pergamon Press, Oxford.

Ryan, R.J. 1994. Preliminary investigations of Meguma Group stratigraphy in the Beaverbank area, Nova Scotia. In Mines and Minerals Branch, Report of Activities, 1993. Nova Scotia Department of Natural Resources, Mines and Energy Branches Report 94-1, pp. 137-140.
Ryan, R.J., Fox, D., Horne, R., Corey, M.C., and Smith, P.K. 1996. Preliminary stratigraphy of the Meguma Group in central Nova Scotia. In Minerals and Energy Branch, Report of Activities 1995. Nova Scotia Department of Natural Resources, Mines and Mineral Branch Report 96-1, pp. 27-34.

Samostie, A. 1994. Assessment of acid drainage risk in Nova Scotia: an application of Geographic Information Systems (GIS). Masters of Environmental Studies (MES) thesis, Dalhousie University, Halifax, Nova Scotia, 170 p.

SANGSTER, A.L. 1990. Metallogeny of the Meguma Terrane, Nova Scotia. In Mineral Deposit Studies in Nova Scotia, Volume 1. Edited by A.L. Sangster. Geological Survey of Canada, Paper 90-8, pp. 115-162.

Schenk, P.E. 1970. Regional variation of the flysh-like Meguma Group (Lower Paleozoic) of Nova Scotia compared to recent sedimentation off the Scotian Shelf. Geological Association of Canada, Special Paper 7, pp. 127-153.

Schwarz, E.J. and Broome, J. 1994. Magnetic Anomalies due to pyrrhotite in Paleozoic metasediments in Nova Scotia, Eastern Canada. Journal of Applied Geophysics, 32, pp. 1-10.

Schwarz, E.J. and McGrath, P.H. 1974. Aeromagnetic anomalies related to pyrrhotite occurrences in the Canadian Appalachian region. Geological Survey of Canada, Paper 741, Current Research, Part B, pp. 107-108.

Silver, M. 1988. Construction of a wetland vegetated system designed to decrease acid and toxic metal loadings from quarry effluents. Marvin Silver Scientific Limited, July, 1988, 16 p.

TAYLOR, F.C. and SCHILLER, E.A. 1966. Metamorphism of the Meguma Group of Nova Scotia. Canadian Journal of Earth Sciences, 3, pp. 959-973.

TAYLOR, L.A. 1971. Oxidation of pyrrhotites and the formation of anomalous pyrrhotite. Carnegie Institution of Washington. Year Book 70, pp. 287-289.

ThOMPSON, B.D. 1978. An investigation of Meguma bedrock leaching in the Shubenacadie-Stewiacke River basin. Technical Report No. 8. Prepared for the Shubenacadie-Stewiacke River Basin Board.

Vaughan, D.J. and Craig, J.R. 1978. Mineral Chemistry of Metal Sulphides. Cambridge University Press, Cambridge.

Worgan, J. 1987. Acid mine drainage in reactive slates, "The Halifax International Airport Case" Transport Canada perspective. In Proceedings, Acid Mine Drainage Seminar/Workshop, Halifax, Nova Scotia, March 23-26, 1987. Environment Canada, pp. 127-135.

WuENsCH, B.J. 1974. Sulphide crystal chemistry. In Sulfide Mineralogy. Edited by P.H. Ribbe. Mineralogical Society of America, Short Course Notes, Volume 1, pp. w21-w43.

Zentilli, M., Graves, M.C., Mulja, T., and Macinnis, I. 1986. Geochemical characterization of the Goldenville-Halifax transition of the Meguma Group of Nova Scotia: preliminary report. Current Research, Part A, Geological Survey of Canada, Paper 86-1A, pp. 423-428. 